\title{
Genetic Variation in Pawpaw Cultivars Using Microsatellite Analysis
}

\author{
Li Lu, Kirk W. Pomper, ${ }^{1,2}$, Jeremiah D. Lowe, and Sheri B. Crabtree \\ Land Grant Program, Kentucky State University, Atwood Research Facility, Frankfort KY \\ 40601-2355
}

\begin{abstract}
AdDITIONAL INDEX wORDs. kentucky banana, SSR, microsatellite motif, genetic diversity, DNA fingerprinting
Abstract. Pawpaw (Asimina triloba) is a tree fruit native to eastern North America, which is in the early stages of domestication. Most early 20th century pawpaw cultivars have been lost; however, recent cultivar releases and potential new releases may have enhanced genetic diversity. The objective of this study was to compare the genetic variation exhibited among older and new pawpaw cultivars and Kentucky State University (KSU) advanced selections using simple sequence repeat (SSR) markers. Polymorphic microsatellite marker analysis was conducted with nine older pawpaw cultivars, six recently released PawPaw Foundation (PPF) cultivars, and nine KSU advanced selections. Using 18 microsatellite loci, a total of 179 alleles were amplified in the set of 24 genotypes. The major allele frequency (0.13 to 0.96 ), number of genotypes (two to 23 ), and allele size (96 to 341 bp) varied greatly by locus. Eighteen loci were highly polymorphic, as indicated by high expected heterozygosity $\left(\mathrm{H}_{\mathrm{e}}=0.71\right)$ and observed heterozygosity $\left(\mathrm{H}_{\mathbf{0}}=\mathbf{0 . 6 5}\right)$ values as well as high polymorphism information content (polymorphism information content $=0.69$ ). The dinucleotide SSR (GA and CA motifs) loci were more polymorphic than trinucleotide (ATG and AAT motifs) SSRs. The PPF cultivars and KSU advanced selections were more closely grouped genetically than with older cultivars. Older cultivars displayed the greatest genetic diversity $\left(\mathrm{H}_{0}=0.69\right)$. The pawpaw cultivar base of older and PPF cultivars does appear to be genetically diverse. However, KSU advanced selections contain unique pawpaw germplasm that should enhance the genetic base of cultivars if these selections are released to the public.
\end{abstract}

The North American pawpaw is a tree fruit native to eastern North America, which is in the early stages of domestication (Pomper et al., 2008a, 2008b; Pomper and Layne, 2005). Pawpaws can be grown successfully in U.S. Department of Agriculture plant hardiness zone 5 (minimum of $-29^{\circ} \mathrm{C}$ ) through zone 8 (minimum of $-7^{\circ} \mathrm{C}$ ) (Kral, 1960). The fruit is very nutritious (Peterson et al., 1982) and has an intense flavor that resembles a combination of banana (Musa acuminate), mango (Mangifera indica), and pineapple (Ananas comosus) (Duffrin and Pomper, 2006; Layne, 1996; Shiota, 1991). This fruit crop has great potential for the processing market (Duffrin and Pomper, 2006; Templeton et al., 2003) as well as fresh market sales at farmers' markets, on-farm sales, and community-supported agriculture (Pomper and Layne, 2005). This plant also contains annonaceous acetogenins in the twigs, fruit, seeds, roots, and bark tissues (McLaughlin, 2008; Pomper et al., 2009b). These compounds display antitumor, pesticidal, antimalarial, anthelmintic, piscicidal, antiviral, and antimicrobial effects, suggesting many potentially useful applications (McLaughlin, 2008).

The pawpaw is diploid $[2 \mathrm{n}=2 \mathrm{x}=18$ (Bowden, 1948; Kral, 1960)]. Flowers are strongly protogynous and are likely selfincompatible (Willson and Schemske, 1980). Pawpaws have dark maroon blossoms that occur singly on the previous year's wood and produce one to nine carpels or one- to 13-fruited clusters (Kral, 1960; Pomper and Layne, 2005). Species whose populations are distributed over a wide geographic region such as Asimina triloba may maintain significant variation among populations (Hamrick and Godt, 1989). In the southern portion of its

Received for publication 11 July 2011. Accepted for publication 24 Aug. 2011. We thank R. Neal Peterson for reviewing the manuscript and for his helpful comments.

${ }^{1}$ Curator, USDA National Clonal Germplasm Repository for Asimina species.

${ }^{2}$ Corresponding author. E-mail: kirk.pomper@kysu.edu. native range, the distribution of $A$. triloba overlaps with that of some subtropical Asimina species, and introgression may have occurred.

From 1900 to 1950, over 50 pawpaw cultivars were selected from the wild and named; however, only two remain: 'Sweet Alice' and 'Middletown' (Peterson, 1991, 2003). The rest of the cultivars appear to have been lost through neglect or abandonment of collections or cannot be identified as a result of loss of records. The loss of cultivars over the past century may have resulted in considerable genetic erosion (Huang et al., 1997; Peterson, 1991). Since 1950, additional pawpaw cultivars have been selected from the wild or developed as a result of breeding efforts of hobbyists (Peterson, 1986, 1991). The PawPaw Foundation breeding program released six pawpaw cultivars in 2004 and 2007. The KSU National Clonal Germplasm Repository (NCGR) for Asimina species in Frankfort, KY (a satellite site of the NCGR in Corvallis, OR) has over 2000 accessions from 17 states in the repository orchards that were collected by enthusiasts and KSU personnel. The repository also contains over 45 cultivars that are currently available from nurseries (Pomper et al., 2009a).

Maintaining a high level of genetic diversity in pawpaw is important for the long-term genetic improvement of the crop and in minimizing vulnerability to disease. A range of DNA and protein-based genetic marker systems has been used in attempts to evaluate genetic diversity in pawpaw. These marker systems include the minisatellite probe (Rogstad et al., 1991), allozymes (Huang et al., 1997, 1998), random amplified polymorphic DNA [RAPD (Huang et al., 2000, 2003)], amplified fragment length polymorphism [AFLP (Wang et al., 2005)], intersimple sequence repeat [ISSR (Pomper et al., 2003)], and SSR (Pomper et al., 2010). Overall, these studies determined that the genetic variation in both cultivated and wild pawpaws is similar to those of other long-lived, temperate woody perennials characterized by a widespread geographic range, insect-pollinated outcrossing breeding 
systems, secondary asexual reproduction, and animal-dispersed seed. The objective of this study was to compare the genetic variation exhibited among older and new pawpaw cultivars and KSU advanced selections using SSR markers.

\section{Materials and Methods}

Plant Material. Leaf samples were collected from older and new (PPF) pawpaw cultivars and KSU advanced selections (Table 1). Leaf samples were collected in Spring 2009 and 2010 from pawpaw trees located at the KSU-NCGR for Asimina species in Frankfort, KY.

DNA EXTRACTION. DNA was extracted from leaves using the DNAMITE Plant Kit (Gel Co., San Francisco, CA). Approximately $2 \mathrm{~cm}^{2}$ of young leaf tissue was used. DNA concentration and 260/280 nm absorbance ratio were determined with a GeneQuant $^{\mathrm{TM}}$ pro RNA/DNA calculator (GE Healthcare Biosciences, Piscataway, NJ). All samples were stored at $-80{ }^{\circ} \mathrm{C}$ until needed.

Microsatellite-ENRICHED Libraries AND PRIMER DESIGN. Genetic Identification Services (GIS, Chatsworth, CA) constructed pawpaw genomic libraries from DNA extracted from the cultivar PA-Golden (\#1); libraries were enriched for di-nucleotide repeat GA (Library B) and for trinucleotide repeat ATG (Library C), and AAT (Library G). Inserts were sequenced by GIS using the DYEnamic ${ }^{\mathrm{TM}}$ ET Terminator Cycle Sequencing Kit (GE Healthcare Biosciences) followed by electrophoresis on a Model 377 DNA Sequencer (Applied Biosystems, Foster City, CA). Primers were designed from flanking regions using DesignerPCR, Version 1.03 (Research Genetics, Huntsville, AL) with the parameters of annealing temperature $60{ }^{\circ} \mathrm{C}$, GC content $50 \%$, and amplicon size of 100 to $350 \mathrm{bp}$. Primer pairs were labeled with FAM or HEX and were made by Integrated DNA Technologies (Coralville, IA).

Simple SEQUENCE REPEAT-POLYMERASE CHAIN REACTION AMPLIFICATION. The SSR-polymerase chain reaction (PCR) amplification was performed with GoTaq Flexi DNA polymerase (Promega, Madison, WI). The reactions were set up as follows: 4 $\mu \mathrm{L}$ of $5 \times$ colorless GoTaq Flexi buffer, $0.4 \mu \mathrm{L}$ of $10 \mathrm{~mm}$ dNTPs solution, $2 \mu \mathrm{L}$ of $25 \mathrm{mM} \mathrm{MgCl}_{2}, 0.3 \mu \mathrm{L}$ of $30 \mu \mathrm{M}$ forward primer (fluorescence labeled with FAM or HEX) solution and $0.3 \mu \mathrm{L}$ of $30 \mu \mathrm{M}$ reverse primer (unlabeled) solution, $0.2 \mu \mathrm{L}$ of 5 units $/ \mu \mathrm{L}$ GoTaq DNA polymerase, $2 \mu \mathrm{L}$ of diluted $1 \mathrm{ng} \cdot \mu \mathrm{L}^{-1}$ pawpaw

Table 1. Genetic background of pawpaw cultivars and selections included in the genetic study.

\begin{tabular}{|c|c|}
\hline Clone & Genetic background $^{\mathrm{z}}$ \\
\hline \multicolumn{2}{|l|}{ Older cultivars } \\
\hline Middletown & Wild seedling from Middletown, OH; selected by E.J. Downing in 1915 \\
\hline $\mathrm{NC}-1$ & 'Davis' female $\times$ 'Overleese' male; selected by R. Douglas Campbell, Ontario, Canada, in 1976. \\
\hline Rebecca's Gold & Seedling from Eaton Rapids, MI; selected by J.M. Riley in 1974 \\
\hline Sunflower & Selected from the wild in Chanute, KS, by M. Gibson in 1970 \\
\hline Sweet Alice & Wild seedling from West Virginia; selected by H. Jacobs in 1945 \\
\hline Taytwo & Wild seedling from Eaton Rapids, MI; selected by C. Davis in 1968 \\
\hline SAA-Zimmerman & Seedling from G.A. Zimmerman collection selected in Amherst, NY, in 1985 \\
\hline \multicolumn{2}{|c|}{ PawPaw Foundation cultivars } \\
\hline Allegheny & Open-pollinated seedling of 'Davis'; selected in 1994 and released in 2007 \\
\hline Potomac & Open-pollinated seedling of BEF-53; selected in 1994 and released in $2007^{y}$ \\
\hline \multicolumn{2}{|c|}{ Kentucky State University advanced selections } \\
\hline G4-21 & Wild seedling from Salem, IN \\
\hline G4-25 & Wild seedling form Ithaca, NY \\
\hline G5-23 & Wild seedling form Ithaca, NY \\
\hline G5-29 & Wild seedling form Ithaca, NY \\
\hline G6-120 & Wild seedling from Maryland \\
\hline G9-109 & Seedling of $11-13^{\mathrm{x}} \times 1-23$ (seedling of 'Taytwo') ${ }^{\mathrm{w}}$ \\
\hline G9-111 & Seedling of 11-13 × 1-23 (seedling of 'Taytwo') \\
\hline K8-2 (KSU-Atwood) & Wild seedling from Maryland \\
\hline Ну3-120 & Seedling of $10-35 \times$ Shenandoah (seedling of 'Overleese') \\
\hline
\end{tabular}

${ }^{\mathrm{z}}$ Genetic relationships of pawpaw derived from Peterson (1991) and investigations by Kentucky State University.

${ }^{\mathrm{y}} \mathrm{BEF}=$ Blandy Experimental Farm collection (Boyce, VA); numerous wild seedlings plus portions of Zimmerman's collection, donated posthumously; assembled by O.E. White and staff at Boyce, VA, from 1926 to 1955.

${ }^{x}$ Numbered selections from the PawPaw Foundation orchards; numerous wild selections from the remnant collections of H.A. Allard (Arlington, VA), Blandy Experimental Farm (Boyce, VA), B. Buckman (Farmington, IL), J. Hershey (Dowington, PA), R. Schlaanstine (West Chester, PA), and G. Zimmerman (Linglestown, PA) plus some from truly wild trees and some from named varieties that were assembled by R.N. Peterson and H. Swartz at the University of Maryland Experiment Stations in Keedysville and Queenstown, MD.

wThe selection 1-23 has previously been incorrectly reported as being a seedling of 'Taylor,' but this selection is actually a seedling of 'Taytwo'. 
DNA, and $10.8 \mu \mathrm{L}$ of $\mathrm{ddH}_{2} \mathrm{O}$ to bring the total volume to $20 \mu \mathrm{L}$. Twenty primers were selected and 15 labeled with FAM: Pp-B3, Pp-B11, Pp-B103, Pp-B108, Pp-B122, Pp-B129, Pp-C4, Pp-C104, Pp-C108, Pp-C109, Pp-G4, Pp-G103, Pp-G112, Pp-G119, and PpG121; five were labeled with HEX: Pp-B117, Pp-B128, Pp-E110, Pp-G124, and Pp-G129 for use in this study (Table 2). The PCR amplifications were performed using the Endurance Series TC512 Thermal Cycler (Techne, Burlington, NJ). The PCR program consisted of an initial period of $94^{\circ} \mathrm{C}$ for $3 \mathrm{~min}$ followed with 30 cycles of $40 \mathrm{~s}$ denaturation at $94^{\circ} \mathrm{C}, 40 \mathrm{~s}$ annealing at $56^{\circ} \mathrm{C}$, and $30 \mathrm{~s}$ extension at $72{ }^{\circ} \mathrm{C}$ and a final extension period of $10 \mathrm{~min}$ at $68{ }^{\circ} \mathrm{C}$. The PCR results were then stored at $4{ }^{\circ} \mathrm{C}$ until analysis. Products were separated with ABI 3130 Genetic Analyzer (Applied Biosystems) with GeneScan ${ }^{\mathrm{TM}} 500 \mathrm{LIZ}^{\mathrm{TM}}$ as an internal size standard. Individuals were genotyped with GeneMapper software (Version 4.0; Applied Biosystems).

Table 2. Primer sequence, fluorescent label, and the simple sequence repeat motif for the primers for 20 microsatellite loci in pawpaw.

\begin{tabular}{|c|c|c|c|}
\hline Locus & Primer sequence & Label & Enriched motif \\
\hline \multirow[t]{2}{*}{ Pp-B3 } & Forward: GCGAAAACGAACATACCTC & FAM & GA \\
\hline & Reverse: CCТCСТCСACСACCACTAC & & \\
\hline \multirow[t]{2}{*}{ Pp-B11 } & Forward: TAGCCTGCCAAGAAATAGAA & FAM & GA \\
\hline & Reverse: CCACCAACTCTGCTTCATAC & & \\
\hline \multirow[t]{2}{*}{ Pp-B103 } & Forward: ATGCCCCAACAGAGACTTC & FAM & GA \\
\hline & Reverse: GGATGAGACACTCGGCTTAC & & \\
\hline \multirow[t]{2}{*}{ Pp-B108 } & Forward: ATCGGGAAAGATGAAAAATCAC & FAM & GA \\
\hline & Reverse: CCTACGCCCTTGTCTCCTT & & \\
\hline \multirow[t]{2}{*}{ Pp-B117 } & Forward: GCATTGGTGTTTAGAACTTCTC & HEX & GA \\
\hline & Reverse: GCACAACAAAAAAGGATAAGAC & & \\
\hline \multirow[t]{2}{*}{ Pp-B122 } & Forward: CTGCTGGAGTGATTGCTAAC & FAM & GA \\
\hline & Reverse: GGAATACAAATGGTGGTGATT & & \\
\hline \multirow[t]{2}{*}{ Pp-B128 } & Forward: GGAAAGGGAAGATGAGTGC & HEX & GA \\
\hline & Reverse: CCATATCTGGCTTCTTTGTTC & & \\
\hline \multirow[t]{2}{*}{ Pp-B129 } & Forward: ACACCAGCCATGATTATGATTC & FAM & GA \\
\hline & Reverse: TCCTTCTCACTCCATCAACAAC & & \\
\hline \multirow[t]{2}{*}{$\mathrm{Pp}-\mathrm{C} 4$} & Forward: AGACAGAGACCACCTAACACTA & FAM & ATG \\
\hline & Reverse: TGATCTAAGGATTTCGATCTG & & \\
\hline \multirow[t]{2}{*}{ Pp-C104 } & Forward: TTTAGCTGACCCCACATAGG & FAM & ATG \\
\hline & Reverse: CAGGAGCCTTACAGGATCAG & & \\
\hline \multirow[t]{2}{*}{ Pp-C108 } & Forward: AAGGCAAAAAGAGGAAAG & FAM & ATG \\
\hline & Reverse: CAGAGAGAAATGGTGTAACAG & & \\
\hline \multirow[t]{2}{*}{ Pp-C109 } & Forward: CGAAGAAGGAAGGGATTC & FAM & ATG \\
\hline & Reverse: GCAAAGAAGAAACAGAAGAAC & & \\
\hline \multirow[t]{2}{*}{ Pp-E110 } & Forward: GGCAACTGTTCTCCCTTC & HEX & $\mathrm{CA}$ \\
\hline & Reverse: CTGCTTTGTGGTAGACTATGC & & \\
\hline \multirow[t]{2}{*}{ Pp-G4 } & Forward: AAATGGCACACTAGGTTTTCA & FAM & AAT \\
\hline & Reverse: TGCTTGCATCCATGAATTAG & & \\
\hline \multirow[t]{2}{*}{ Pp-G103 } & Forward: AGCCAAAATCAAGAAACC & FAM & AAT \\
\hline & Reverse: CTGCTCAGGGTCACTACA & & \\
\hline \multirow[t]{2}{*}{ Pp-G112 } & Forward: CTTATTAGGGCTTGCATTCATC & FAM & AAT \\
\hline & Reverse: GCCCCATAAACCTATATGTGAA & & \\
\hline \multirow[t]{2}{*}{ Pp-G119 } & Forward: AAACCGTAGTAAAACCAGACAA & FAM & AAT \\
\hline & Reverse: GGATAGGAAAACATGGTGATTA & & \\
\hline \multirow[t]{2}{*}{ Pp-G121 } & Forward: TTGCCAACTATCCGCTATTTA & FAM & AAT \\
\hline & Reverse: GCCATACAAGACCAACAAAGA & & \\
\hline \multirow[t]{2}{*}{ Pp-G124 } & Forward: GTAGCCAGGAGGAGATGAACT & HEX & AAT \\
\hline & Reverse: GGTGATTGGATTGCCTAAAAT & & \\
\hline \multirow[t]{2}{*}{ Pp-G129 } & Forward: GCGTCCACACAGTCTCAT & HEX & AAT \\
\hline & Reverse: CGGCATTTATTTTCCATCT & & \\
\hline
\end{tabular}

Data AnAlysis. PowerMarker Version 3.25 (Liu and Muse, 2005) was used to calculate the major allele frequency, number of genotypes, observed number of alleles, $\mathrm{H}_{\mathrm{o}}, \mathrm{H}_{\mathrm{e}}$, and polymorphism information content (PIC) for all accessions. The major allele frequency is the frequency of the most common allele. The $\mathrm{H}_{\mathrm{o}}$ was calculated as the number of heterozygous genotypes at a given locus divided by the number of genotypes present at the locus. Gene diversity was defined as the probability that two randomly chosen alleles from the population are different. PIC was an estimate that the parental origin of an allele can be determined from the marker locus genotype in any given offspring. The equation for $\mathrm{H}_{\mathrm{o}}, \mathrm{H}_{\mathrm{e}}$, and PIC are given in the PowerMarker software manual. Genetic distance (D) between genotypes was computed as ( 1 - proportion of shared alleles) (Bowcock et al., 1994). The frequency of null alleles was calculated as $\mathrm{r}=\left(\mathrm{H}_{\mathrm{e}}-\mathrm{H}_{\mathrm{o}}\right) /\left(1+\mathrm{H}_{\mathrm{e}}\right)$ (Botstein et al., 1980). The distance data were used to generate an unweighted pair group method with an arithmetic mean (UPGMA) dendrogram.

\section{Results}

Initial sequencing of 34 inserts from libraries enriched for di-nucleotide repeats GA and $\mathrm{CA}$ as well as for trinucleotide repeats ATG and AAT motifs led to the development of a number of promising primer sets. After initial screening, 20 primer sets showed great promise for fingerprinting and genetic diversity studies in pawpaw cultivars (Table 2). All primers yielded strong and reproducible marker peaks. Because the loci Pp-C4 (172 bp and ATG motif) and Pp-G129 (249 bp and AAT motif) each had monomorphic alleles, they were not included in the further genetic analysis or dendrogram development. The loci Pp-B3, Pp-103, Pp-B129, Pp-C104, and Pp-G119 were successfully used to amplify products by Pomper et al. (2010); however, 13 additional primers that amplified polymorphic markers were identified in this study.

There were between two and 22 allelic forms per locus for the genotypes examined, but there were never more than two allelic forms for each locus for each genotype. There were 179 allelic forms (amplicons) across all 18 loci for all genotypes (Table 3). Major allele frequency $(0.13$ to 0.96$)$, number of genotypes (two to 23), and allele size (96 to 341 bp) varied greatly by locus. Most loci were highly polymorphic, as indicated by values for $\mathrm{H}_{\mathrm{e}}, \mathrm{H}_{\mathrm{o}}$, and PIC. The $\mathrm{H}_{\mathrm{o}}(0.65)$ and $\mathrm{H}_{\mathrm{e}}(0.71)$ were similar and $r=0.03$ indicated few null alleles. The GA motif loci had a major allele frequency $(0.27)$, number of genotypes (17.9), $\mathrm{H}_{\mathrm{e}}(0.84)$, and $\mathrm{H}_{\mathrm{o}}(0.63)$. The ATG motif loci had a major allele frequency (0.46), number of genotypes (12.8), $\mathrm{H}_{\mathrm{e}}(0.66)$, and $\mathrm{H}_{\mathrm{o}}(0.52)$. The AAT motif loci had a major allele frequency $(0.48)$, number of genotypes (10.8), $\mathrm{H}_{\mathrm{e}}(0.66)$, and $\mathrm{H}_{\mathrm{o}}(0.63)$. There was only one CA motif loci included in 
Table 3. Major allele frequency, number of genotypes, observed number of alleles, allele size in base pairs (bp), expected heterozygosity ( $\left.\mathrm{H}_{\mathrm{e}}\right)$, observed heterozygosity $\left(\mathrm{H}_{\mathrm{o}}\right)$, polymorphism information content (PIC), and frequency of null alleles (r) for all pawpaw cultivars and advanced selections and also by microsatellite motif.

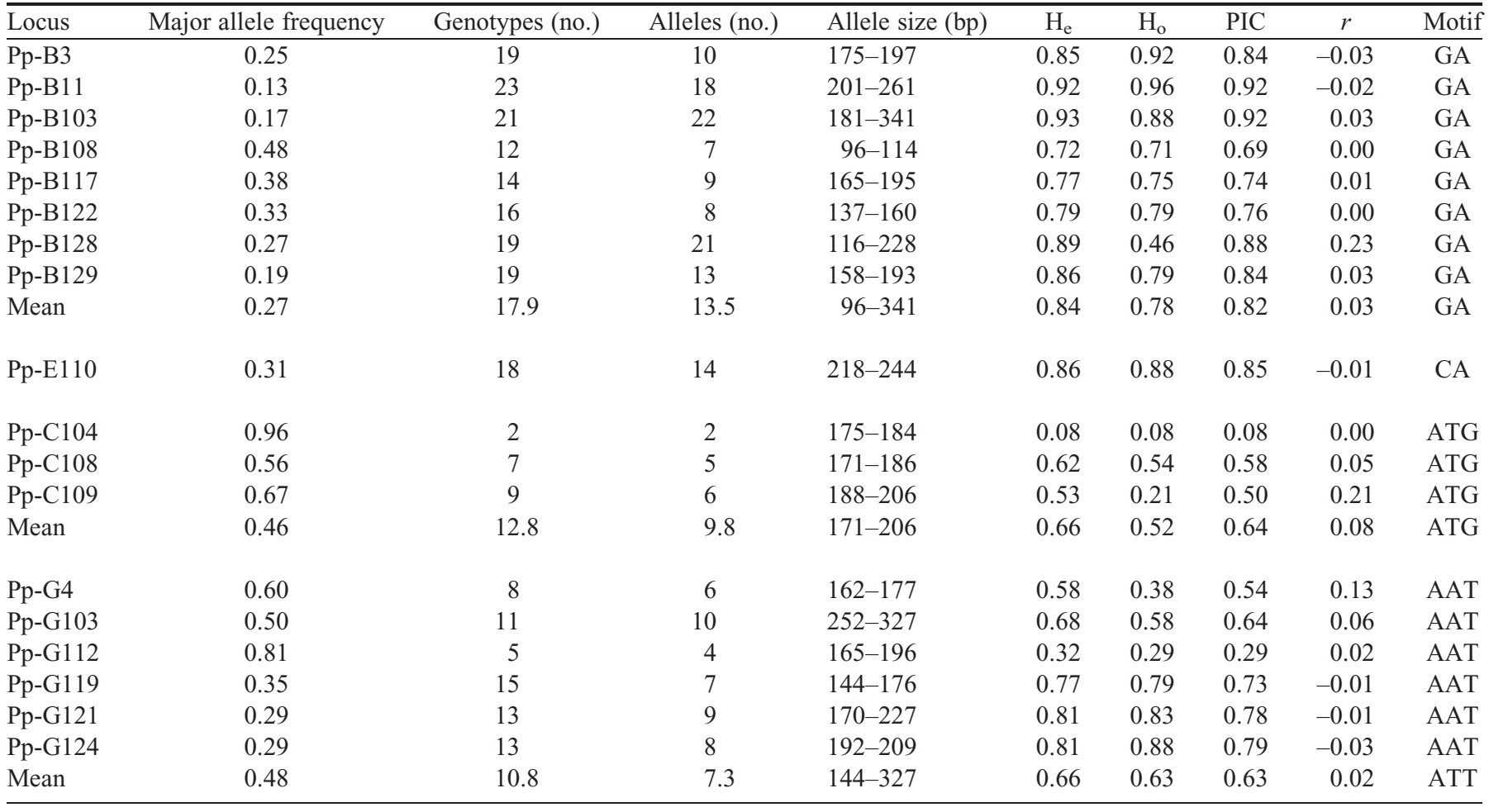

the study, and the genetic characteristics resembled the GA motif values.

In the 24 genotypes, all had unique marker fingerprints. All genotypes were separated using a UPGMA dendrogram, which depicts the genetic relationships among the cultivars and advanced selections (Fig. 1). When examining all genotypes separately, the selections G4-21 and G4-25 were genetically very dissimilar to all other genotypes examined. Beyond this point in separation in the dendrogram, there were a number of small groupings of selections that were genetically similar to each other.

The pawpaw cultivars Rappahannock, Wabash, and Potomac were grouped together (Fig. 1); all three were seedlings from trees in the Blandy Experimental Farm collection in Boyce, VA. The selections G5-23 and G5-29 are seedlings from a New York population; therefore, genetic similarity was not unexpected. The selections G9-109 and G9-111 are half-sibs and were also closely grouped to each other; they also shared genetic similarity to the cultivar Taytwo. Two pawpaw cultivars, Rebecca's Gold and NC-1, displayed very similar fingerprints and were genetically very similar to each other, although these selections have very different genetic origins. 'Shenandoah', Hy3-120, 'Allegheny', and 'Overleese' were grouped together, which is not surprising because Hy3-120 is a seedling of 'Shenandoah' and 'Shenandoah' is a seedling of 'Overleese'. 'Allegheny' does not share a known common lineage with these selections. 'Zimmerman', 'Sunflower', and 'Taylor' are genetically distinct from the other older and newer cultivars in this study.

When comparing the three groups of older pawpaw cultivars, recently released PPF cultivars, and KSU advanced selections, the older cultivars had the highest $\mathrm{H}_{\mathrm{o}}=0.69$, indicating this group contained the greatest genetic diversity (Table 4). However, when the KSU advanced selections Hy3-120, G9-109, and G9-111, which are seedlings of PPF cultivars or PPF advanced selections, were removed from genetic analysis, the remaining KSU advanced selections had the highest $\mathrm{H}_{\mathrm{o}}=0.70$ and displayed slightly higher genetic diversity than older cultivars. Separating the three pawpaw groups in an UPGMA dendrogram showed that the PPF cultivars were more closely grouped with the KSU advanced selections group and that the older cultivars were genetically more distant (data not shown). When Hy3-120, G9-109, and G9-111 were removed from genetic analysis, the remaining KSU selections were genetically more distant from the older and PPF cultivars. The KSU advanced selections had 30 unique alleles in eight individuals (3.8 alleles/individual), the older cultivars had 41 unique alleles in nine individuals (4.6 alleles/individual), and the PPF cultivars had nine unique alleles in six individuals (1.5 alleles/individual).

\section{Discussion}

Maintaining diverse germplasm available to plant breeders is important to the long-term genetic improvement of any crop. Although older selections were lost 70 to 80 years ago, the North American pawpaw is in a favorable position to have diverse and superior germplasm identified and maintained, because it is in the early stages of domestication and the wild population is thriving over an extensive territory. Eighteen polymorphic SSR loci, including 13 new loci, were used for fingerprinting and genetic analysis in pawpaw. These SSR loci were useful in examining whether genetically unique cultivars are being developed to enhance the genetic diversity of pawpaw cultivars. This is the 


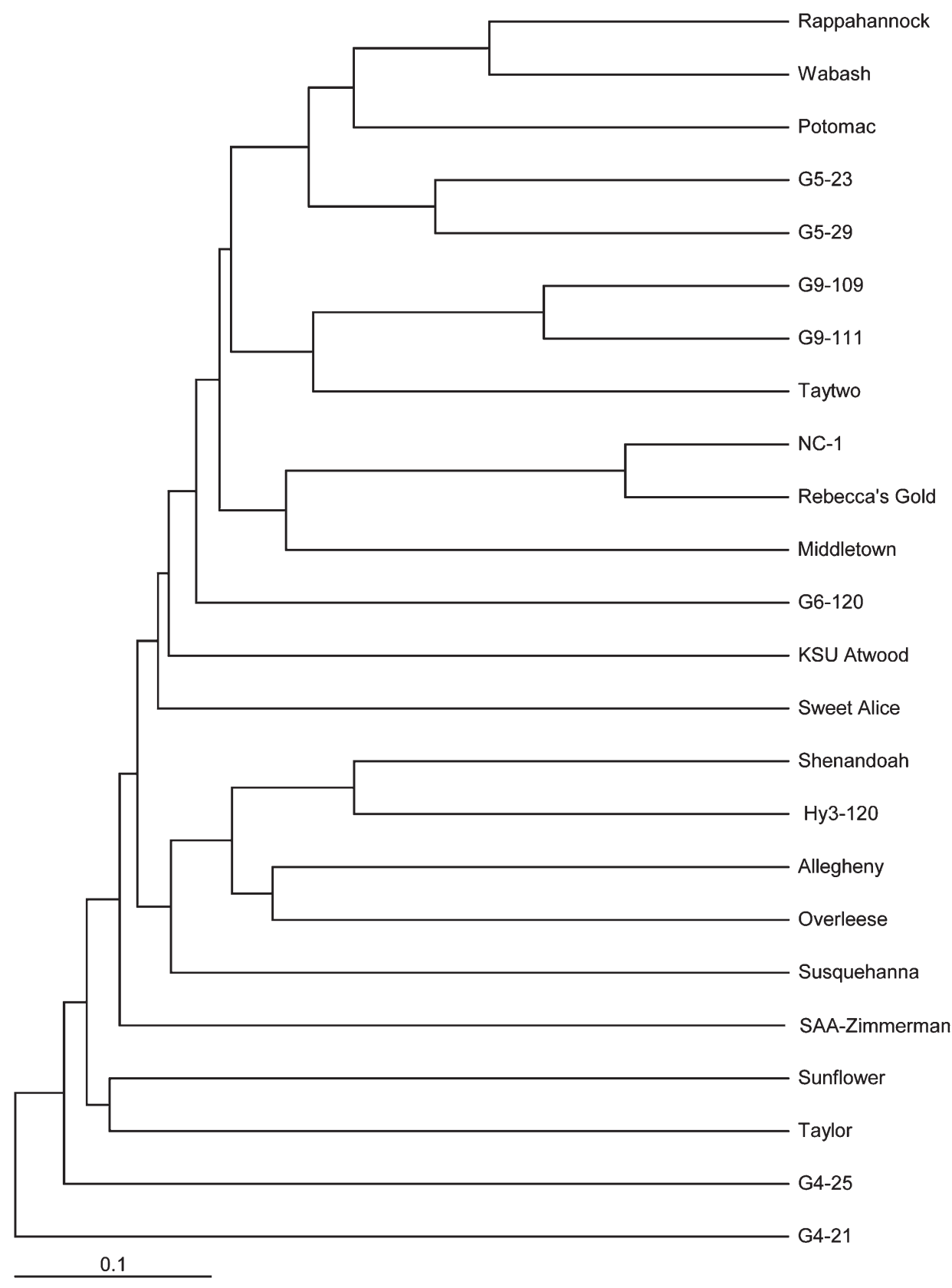

Fig. 1. Unweighted pair group method with an arithmetic mean dendrogram of 24 pawpaw genotypes based on 18 microsatellite loci and shared allele distance, in which the difference of genetic distance (D) between the genotypes computed as ( 1 - proportion of shared alleles). Older cultivars are: Middletown, NC-1, Overleese, Rebecca's Gold, Sunflower, Sweet Alice, Taylor, Taytwo, and SAA-Zimmerman. PawPaw Foundation cultivars are: Allegheny, Potomac, Rappahannock, Shenandoah, Susquehanna, and Wabash. Kentucky State University advanced selections are: G4-21, G4-25, G5-23, G5-29, G6-120, G9-109, G9-111, K8-2 (KSU-Atwood), and Hy3-120.

first report of the influence of SSR motif on the marker polymorphism in pawpaw. The CA motif SSR loci appeared to have greater allele numbers and higher $\mathrm{H}_{\mathrm{e}}$ and $\mathrm{H}_{\mathrm{o}}$ than ATG and AAT loci motifs. The AT and GA repeats are the most common dinucleotide repeats in plants (Bassil et al., 2005; Cardle et al., 2000; Lagercrantz et al., 1993; Morgante and Olivieri, 1993). Nine trinucleotide microsatellites and nine di-nucleotide microsatellite SSRs were examined in this study and the difference in polymorphisms was apparent. The tri-SSRs were more homozygous $\left(\mathrm{H}_{\mathrm{o}}=0.58\right.$ vs. 0.83 for tri-SSRs vs. di-SSRs, respectively $)$ and less informative than di-nucleotide SSRs in pawpaw selections as indicated by a lower mean number of alleles per locus ( 8.5 vs. 13.5) and $\mathrm{H}_{\mathrm{e}}$ (0.66 vs. 0.84$)$. Similar differences in the level of polymorphism between the two classes of microsatellites (diSSRs vs. tri-SSRs) have been reported in other plant species (Bassil et al., 2005; Huttel et al., 1999; Rossetto et al., 1999; Scotti et al., 2002). Therefore, it is not surprising that the tri-SSR motif loci Pp-C4 (ATG motif) and Pp-G129 (AAT motif) displayed monomorphic alleles in pawpaw and were dropped from further genetic analysis in this study.

The SSR markers yielded unique fingerprinting for all the pawpaw accessions examined. The dendrogram of pawpaw genotypes constructed from SSR marker data is similar in many respects to that constructed using other types of markers. Markers used in previous studies include RAPDs (Huang et al., 2003), AFLPs (Wang et al., 2005), ISSRs (Pomper et al., 2003), and SSRs (Pomper et al., 2010) in which only five SSR loci were used for separation. Fingerprints confirmed the various genetic backgrounds of selections and their offspring. Both Huang et al. (2003), using RAPD markers, and Pomper et al. (2010), with a limited number of SSR makers, placed 'Overleese' and its seedling 'Shenandoah' in a similar grouping as we did in this study. Wang et al. (2005), using AFLP markers, and Pomper et al. (2010), using SSR markers, showed that 'Taytwo' and 1-23 (a seedling of 'Taytwo') were closely related. In this study, the KSU advanced selections of G9-109 and G9-111, who share a parent of 1-23, were both also grouped together with 'Taytwo'. Pomper et al. $(2003,2010)$ were unable to distinguish between 'Rebecca's Gold' and 'NC-1' using either ISSR or limited SSR markers; however, unique fingerprints were generated for these two cultivars using the 18 SSR loci in the study. These selections remain closely grouped together, although leaf morphology and fruiting characteristics are quite different between the two cultivars.

A high level of genetic diversity was detected in the pawpaw genotypes. The high average number of alleles per locus (13.5) is comparable to that in other outcrossing woody perennial fruit and nut crop species such as 13.3 alleles per locus reported for hazelnut [Corylus avellana (Bassil et al., 2005)], 9.5 per locus for avocado [Persea americana (Lavi et al., 1994)], 12.1 for apple 
Table 4. Major allele frequency, number of genotypes, observed number of alleles, expected heterozygosity $\left(\mathrm{H}_{\mathrm{e}}\right)$, observed heterozygosity $\left(\mathrm{H}_{\mathrm{o}}\right)$, and polymorphism information content (PIC) for older pawpaw cultivars, PawPaw Foundation (PPF) cultivars, and Kentucky State University (KSU) advanced selections as well as KSU advanced selections excluding Hy3-120, G9-109, and G9-111 from analysis.

\begin{tabular}{lccccc}
\hline Group & $\begin{array}{c}\text { Major allele } \\
\text { frequency }\end{array}$ & Genotypes (no.) & Alleles (no.) & $\mathrm{H}_{\mathrm{e}}$ & $\mathrm{H}_{\mathrm{o}}$ \\
\hline Older cultivars & 0.42 & 6.3 & 7.3 & 0.71 & 0.69 \\
PPF cultivars & 0.53 & 4.3 & 4.3 & 0.69 \\
KSU advanced selections & 0.43 & 6.6 & 6.6 & 0.58 & 0.55 \\
KSU advanced selections & 0.42 & 4.9 & 0.54 \\
$\quad$ without three PPF related selections & & & 0.69 & 0.69 & 0.66 \\
\hline
\end{tabular}

[Malus $\times$ domestica (Hokanson et al., 1998)], and 9.1 for pear [Pyrus communis (Sisko et al., 2009). Tree species with lower reported average alleles per locus include olive (Olea europaea) with 5.5 (Noormohammadi et al., 2007), peach (Prunus persica) at 2.2 (Ahmad et al., 2004), and avocado in Ghana at 4.4 (Acheampong et al., 2008). In cherimoya (Annona cherimola), which is in the same family (Annonaceae), Escribano et al. (2008) reported averages of only 4.9 alleles per locus, $\mathrm{H}_{\mathrm{e}}=0.53$ and $\mathrm{H}_{\mathrm{o}}=0.44$. Pomper et al. (2010) reported a similar $\mathrm{H}_{\mathrm{e}}(0.70)$, $\mathrm{H}_{\mathrm{o}}$ (0.68), and PIC (0.68) values with fewer SSR loci and different pawpaw genotypes compared with $\mathrm{H}_{\mathrm{e}}(0.71), \mathrm{H}_{\mathrm{o}}(0.65)$, and PIC (0.69) in this study, indicating high levels of genetic diversity among the pawpaw genotypes examined.

The development of superior pawpaw cultivars in terms of fruit quality and yield and the enhancement of genetic diversity contained in cultivars that are available to the public is crucial to the continued commercialization of pawpaw. High levels of genetic diversity exist in A. triloba (Huang et al., 1997, 1998, 2000; Pomper et al., 2003, 2010; Wang et al., 2005), which is consistent with frequent seed reproduction and adaptation of different environments. Grouping of genotypes in an unweighted pair group method with an arithmetic mean dendrogram showed that the PPF cultivars were more closely grouped with KSU advanced selections and that the older cultivars were genetically more distant than KSU or PPF selections unique genotypes. Most of the older cultivars were selected from the wild by pawpaw enthusiasts; therefore, these cultivars likely reflect the diverse wild populations found across the pawpaw's native range. The PPF cultivars were mainly selected from seedlings obtained from sites that were thought to contain surviving trees of abandoned collections of older pawpaw cultivars that have been lost from cultivation (Peterson, 2003). Although still genetically diverse, some seedlings from these collections likely shared some common genetic backgrounds (e.g., half-sibs) making the PPF cultivars less diverse than the older pawpaw cultivars. Several KSU advanced selections share a genetic background with the PPF selections; Hy3-120, G9-109, and G9-111 are seedlings of PPF cultivars or PPF advanced selections. Most of the KSU advanced selections are from separate collection efforts in the wild by pawpaw enthusiasts (e.g., G-4-21, G4-25, G5-23, G529, G6-120, and K8-2) outside of PPF cultivar selection efforts. When examining all genotypes separately, the selections G4-21 and G4-25 were genetically very dissimilar to all other genotypes examined. The three seedlings of PPF cultivars or PPF advanced selections reduced the overall diversity of the KSU advanced selections. When Hy3-120, G9-109, and G9-111 were removed from genetic analysis, the remaining KSU selections were genetically more diverse than the older PPF cultivars. The $\mathrm{KSU}$ advanced selections represent a combination of desirable traits observed in the repository orchards that included combinations of large fruit size, high yields, late flowering, unique flavors, and fruit quality. The KSU advanced selection K8-2 has been propagated, undergone field trials, and was recently released as KSU-Atwood ${ }^{\mathrm{TM}}$. This cultivar is being sold to the public by nurseries. The remaining KSU advanced selections have been propagated and are undergoing field trials. A number of these selections may be released by KSU in the future.

In conclusion, 18 pawpaw microsatellite loci were identified and SSR primer sets developed to fingerprint and assess genetic diversity in pawpaw cultivars and advanced selections from the KSU breeding program. The di-nucleotide SSR (GA and CA motifs) loci were more polymorphic than trinucleotide (ATG and AAT motifs) SSRs. The pawpaw cultivar base of older and PPF cultivars does appear to be genetically diverse. However, KSU advanced selections contain unique pawpaw germplasm that should enhance the pawpaw cultivar base if these selections are released to the public. Future breeding efforts at KSU and by PPF should include diverse genotypes to ensure high levels of genetic diversity in pawpaw cultivars.

\section{Literature Cited}

Acheampong, A.K., R. Akromah, F.A. Ofori, J.F. Takrama, D. Saada, I. Bitton, and U. Lavi. 2008. Genetic characterization of Ghanaian avocados using microsatellite markers. J. Amer. Soc. Hort. Sci. 133: 801-809.

Ahmad, R., D. Potter, and S.M. Southwick. 2004. Genotyping of peach and nectarine cultivars with SSR and SRAP molecular markers. J. Amer. Soc. Hort. Sci. 129:204-210.

Bassil, N.V., R. Botta, and S.A. Mehlenbacher. 2005. Microsatellite markers in hazelnut: Isolation, characterization, and cross-species amplification. J. Amer. Soc. Hort. Sci. 130:543-549.

Botstein, D., R.L. White, M. Skolnick, and R.W. Davis. 1980. Construction of a genetic linkage map in man using restriction fragment length polymorphisms. Amer. J. Hum. Genet. 32:314-331. Bowcock, A.M., A. Ruis-Linares, J. Tomfohrde, E. Minch, J.R. Kidd, and L.L. Cavalli-Sforza. 1994. High resolution of human evolutionary trees from polymorphic microsatellites. Nature 368:455-457.

Bowden, W.M. 1948. Chromosome numbers in the Annonaceae. Amer. J. Bot. 35:377-381.

Cardle, L., L. Ramsay, D. Milbourne, M. Macauly, D. Marshall, and R. Waugh. 2000. Computational and experimental characterization of physically clustered simple sequence repeats in plants. Genetics 156:847-854.

Duffrin, M.W. and K.W. Pomper. 2006. Development of flavor descriptors for pawpaw fruit puree: A step toward the establishment of a native tree fruit industry. Fam. Consum. Sci. Res. J. 35:118-130.

Escribano, P., M.A. Viruel, and J.I. Hormaza. 2008. Development of 52 new polymorphic SSR markers from cherimoya (Annona cherimola Mill.): Transferability to related taxa and selection of a reduced set for DNA fingerprinting and diversity studies. Mol. Ecol. Resources $8: 317-321$. 
Hamrick, J.L. and M.J.W. Godt. 1989. Allozyme diversity in plant species, p. 43-63. In: Brown, A.H.D., M.T. Clegg, A.L. Kahler, and B.S. Weir (eds.). Plant population genetics, breeding and genetic resources. Sinauer Associates, Sunderland, MA.

Hokanson, S.C., A.K. Szewc-McFadden, W.F. Lamboy, and J.R. McFerson. 1998. Microsatellite (SSR) markers reveal genetic identities, genetic diversity, and relationships in a Malus $\times$ domestica Borkh. core subset collection. Theor. Appl. Genet. 97:671-683.

Huang, H., D.R. Layne, and T.L. Kubisiak. 2000. RAPD inheritance and diversity in pawpaw (Asimina triloba). J. Amer. Soc. Hort. Sci. 125:454-459.

Huang, H., D.R. Layne, and T.L. Kubisiak. 2003. Molecular characterization of cultivated pawpaw (Asimina triloba) using RAPD markers. J. Amer. Soc. Hort. Sci. 128:85-93.

Huang, H., D.R. Layne, and R.N. Peterson. 1997. Using isozyme polymorphisms for identifying and assessing genetic variation in cultivated pawpaw. [Asimina triloba (L.) Dunal]. J. Amer. Soc. Hort. Sci. 122:504-511.

Huang, H., D.R. Layne, and D.E. Riemenschneider. 1998. Genetic diversity and geographic differentiation in pawpaw [Asimina triloba (L.) Dunal] populations from nine states as revealed by allozyme analysis. J. Amer. Soc. Hort. Sci. 123:635-641.

Huttel, B., P. Winter, K. Weising, W. Choumane, F. Weigand, and G. Kahl. 1999. Sequence-tagged microsatellite site markers for chickpea (Cicer arietinum L.). Genome 42:210-217.

Kral, R. 1960. A revision of Asimina and Deeringothamnus (Annonaceae). Brittonia 12:233-278.

Lagercrantz, U., H. Ellegran, and L. Anderson. 1993. The abundance of various polymorphic microsatellite motifs differs between plants and vertebrates. Nucleic Acids Res. 21:1111-1115.

Lavi, U., M. Akkaya, A. Bhagwat, E. Lahav, and P.B. Cregan. 1994. Methodology of generation and characteristics of simple sequence repeat DNA markers in avocado (Persea americana M.). Euphytica 80:171-177.

Layne, D.R. 1996. The pawpaw [Asimina triloba (L.) Dunal]: A new fruit crop for Kentucky and the United States. HortScience 31:777-784.

Liu, K. and S.V. Muse. 2005. PowerMarker: Integrated analysis environment for genetic marker data. Bioinformatics 21:2128-2129.

McLaughlin, J.L. 2008. Paw paw and cancer: Annonaceous acetogenins from discovery to commercial products. J. Nat. Prod. 71:1311-1321.

Morgante, M. and A.M. Olivieri. 1993. PCR-amplified microsatellites as markers in plant genetics. Plant J. 3:175-182.

Noormohammadi, Z., M. Hosseini-Mazinani, I. Trujillo, L. Rallo, A. Belaj, and M. Sadeghizadeh. 2007. Identification and classification of main Iranian olive cultivars using microsatellite markers. HortScience 42:1545-1550.

Peterson, R.N. 1986. Research on the pawpaw (Asimina triloba) at the University of Maryland. 77th Annu. Rpt. Northern Nut Growers Assn. 77:73-78.

Peterson, R.N. 1991. Pawpaw (Asimina). Acta Hort. 290:567-600.

Peterson, R.N. 2003. Pawpaw variety development: A history and future prospects. HortTechology 13:449-454.
Peterson, R.N., J.P. Cherry, and J.G. Simmons. 1982. Composition of pawpaw (Asimina triloba) fruit. Annu. Rpt. Northern Nut Growers Assn. 73:97-107.

Pomper, K.W., S.B. Crabtree, S.P. Brown, S.C. Jones, T.M. Bonney, and D.R. Layne. 2003. Assessment of genetic diversity of pawpaw varieties with inter-simple sequence repeat markers. J. Amer. Soc. Hort. Sci. 128:521-525.

Pomper, K.W., S.B. Crabtree, D.R. Layne, and R.N. Peterson. 2008 a. Flowering and fruiting characteristics of eight pawpaw (Asimina triloba) selections in Kentucky. J. Amer. Pomol. Soc. 62:89-97.

Pomper, K.W., S.B. Crabtree, D.R. Layne, R.N. Peterson, J. Masabni, and D. Wolfe. 2008b. The Kentucky pawpaw regional variety trial. J. Amer. Pomol. Soc. 62:58-69.

Pomper, K.W., S.B. Crabtree, and J.D. Lowe. 2009a. Pawpaw cultivar list and fruit photographs. 26 Feb. 2010. <http://www.pawpaw.kysu.edu/ pawpaw/cvsrc98.htm>.

Pomper, K.W., J.D. Lowe, S.B. Crabtree, and W. Keller. 2009b. Identification of annonaceous acetogenins in the ripe fruit of the North American pawpaw (Asimina triloba). J. Agr. Food Chem. 57:8339-8343.

Pomper, K.W. and D.R. Layne. 2005. The North American pawpaw: Botany and horticulture. Hort. Rev. 31:351-384.

Pomper, K.W., J.D. Lowe, L. Lu, S.B. Crabtree, S. Dutta, K. Schneider, and J. Tidwell. 2010. Characterization and identification of pawpaw (Asimina triloba) cultivars and advanced selections by simple sequence repeat markers. J. Amer. Soc. Hort. Sci. 135:143-149.

Rogstad, S.H., K. Wolff, and B.A. Schaal. 1991. Geographical variation in Asimina triloba Dunal (Annonaceae) revealed by the M13 DNA fingerprinting probe. Amer. J. Bot. 78:1391-1396.

Rossetto, M., A. McLauchlan, F.C.L. Harriss, R.J. Henry, P.R. Braverstock, L.S. Lee, T.L. Maguire, and K.J. Edwards. 1999. Abundance and polymorphism of microsatellite markers in the tea tree (Melaleuca alternifolia, Myrtaceae). Theor. Appl. Genet. 98:1091-1098.

Scotti, I., G.P. Paglia, F. Magni, and M. Morgante. 2002. Efficient development of dinucleotide microsatellite markers in norway spruce (Picea abies Karst.) through dot-blot selection. Theor. Appl. Genet. 104:1035-1041.

Shiota, H. 1991. Volatile components of pawpaw fruit (Asimina triloba Dunal). J. Agr. Food Chem. 39:1631-1635.

Sisko, M., B. Javornik, A. Siftar, and A. Ivancic. 2009. Genetic relationships among Slovenian pears assessed by molecular markers. J. Amer. Soc. Hort. Sci. 134:97-108.

Templeton, S.B., M. Marlette, K.W. Pomper, and S.C. Jones. 2003. Favorable taste ratings for several pawpaw products. HortTechnology 13:445-448.

Wang, Y., G.L. Reighard, D.R. Layne, A.G. Abbott, and H. Huang. 2005. Inheritance of AFLP markers and their use for genetic diversity analysis in wild and domesticated pawpaw [Asimina triloba (L.) Dunal]. J. Amer. Soc. Hort. Sci. 130:561-568.

Willson, M.F. and D.W. Schemske. 1980. Pollinator limitation, fruit production, and floral display in pawpaw (Asimina triloba). Bull. Torrey Bot. Club 107:401-408. 